\title{
Abstracts/Résumés
}

\section{Harmonic Scales as Faithfulness}

\author{
Darin Howe, University of Calgary \\ Douglas Pulleyblank, University of British Columbia
}

\begin{abstract}
Optimality Theory predicts that harmonic scales can be encoded in grammar in one of two ways: either as markedeness hierarchies or else as faithfulness hierarchies. Although most current researchers assume that harmony is encoded as markedness, many investigators have argued that some harmonic relations are better captured as faithfulness hierarchies that prevent the deletion or insertion of less harmonic elements. We demonstrate that at least two perceptually-motivated harmonic scales - notably relative vowel height as well as consonant glottalisation - need to be encoded in the grammar as faithfulness hierarchies which require that more harmonic elements, which are also more perceptible, are more faithfully adhered to. Our harmony-as-faithfulness analysis captures the fact that the same elements which undergo deletion also undergo insertion.
\end{abstract}

\section{Résumé}

La théorie d'optimalité prédit que les hiérarchies harmoniques peuvent être encodées dans la grammaire de deux façons : soit comme une hiérarchie de marquage, ou comme une hiérarchie de fiabilité. Malgré le fait que la plupart des chercheurs prennent pour acquis l'idée que l'harmonie est encodée en terme de marquage, plusieurs linguistes ont proposés qu'il est préférable de concevoir les relations harmoniques comme étant des hiérarchies de fiabilité qui empêchent l'élision ou l'insertion des éléments moins harmoniques. Nous démontrons qu'au moins deux hiérarchies harmoniques - notamment la hauteur relative des voyelles ainsi que la glottalisation des consonnes - doivent être encodées dans la grammaire comme des hiéarchies de fiabilité qui exigent que les élements plus harmoniques, qui sont aussi plus perceptibles, sont respectées de façon plus fiable. Notre analyse d'harmonie-comme-fiabilité rends compte du fait que les mêmes éléments qui subissent l'élision subissent aussi l'insertion. 


\title{
On the Sources of Person Hierarchy Effects in Halkomelem Salish
}

\author{
Martina Wiltschko, University of British Columbia \\ Strang Burton, Sto:lo Shxweli Halq'emeylem Language Program
}

\begin{abstract}
Like many other Salish languages, in Halkomelem Salish, with transitive verbs, it is not possible to combine a 3rd person with a 2 nd person. We propose that this $* 3 / 2$ constraint is morphological in nature. This departs from previous analyses which have taken the $* 3 / 2$ constraint to be the effect of a hierarchy of [person] and/or [animate] features. One consequence of analysing the $* 3 / 2$ constraint as morphologically based is that person/animacy hierarchies are not primitives in the grammar. In particular, we show that person-based gaps in transitive verb paradigms receive a morpho-syntactic explanation, and that apparent restrictions on the distribution of the [animate] feature actually reflect the lexical semantics of the predicate.
\end{abstract}

\section{Résumé}

Comme dans plusieurs langues Salishennes, en Halkomelem Salish il n'est pas possible, avec un verbe transitif, de combiner une $3^{\text {ième }}$ personne avec une $2^{\text {ième }}$ personne. Nous proposons que cette contrainte $* 3 / 2$ est de nature morphologique. Cette approche se distinguent des analyses antérieures qui traitaient la contrainte *3/2 comme étant l'effet d'une hiérarchie de traits de [personne] et/ou de traits d' [animé]. L'analyse de la contrainte $* 3 / 2$ en termes morphologiques a comme conséquence que les hiérarchies de traits de [personne] ou [animé] ne sont pas des éléments primitifs dans la grammaire. En particulier, nous démontrons que les trous dans les paradigmes des verbes transitifs reçoivent une explication morphosyntaxique, et que les restrictions apparentes sur la distribution du trait [animé] sont en réalité l'effet de la sémantique lexicale du prédicat. 


\title{
Academic Career Paths in Linguistics: A Report on the CLA Questionnaire
}

\author{
Patricia Balcom, Université de Moncton \\ Sandra Clarke, Memorial University of Newfoundland
}

\begin{abstract}
This paper presents the results of a survey conducted by the CLA in 1996-1997. Mail-in questionnaires were completed by 110 Canadian linguists from all regions of the country, 71 of whom (65\%) were female, and $39(35 \%)$ male. Following an overview of the literature dealing with women in academia in general and linguistics in particular, a summary of the background and status of the respondents is given. The results are presented thematically, exploring (i) the division between teaching, research and committee work; (ii) mentoring; (iii) financial support; (iv) the relative prestige of sub-disciplines. Of note is the fact that SPSS analyses show very few significant differences when sex was taken as a variable. The quantitative results provide a snapshot of linguistics in Canada in the late 1990s, and coupled with the numerous comments provided by respondents, point to issues that need to be addressed by the Canadian Linguistics Association. These are summarized in the Conclusion as a series of recommendations to the Association.
\end{abstract}

\section{Résumé}

Cet article présente les résultats d'un sondage effectué par l'ACL entre 1996 et 1997. 110 linguistes représentant toutes les régions du Canada ont complêté un questionnaire postal, dont $71(65 \%)$ femmes et $39(35 \%)$ hommes. Après un recensement des écrits au sujet des femmes universitaires en général et les femmes en linguistique en particulier, un résumé des données démographiques des répondantes et des répondants est donné. Ensuite les résultats du questionnaire sont présentés thématiquement: (i) la répartition entre l'enseignement, la recherche et la service à la collectivité ; (ii) le réseau d'appuis; (iii) le support financier; (iv) le prestige relatif des sous-disciplines. À noter est le fait que les analyses SPSS ont trouvé très peu de différences significatives en considérant le sexe comme variable. Ces résultats quantitatifs offrent un instantané de la linguistique au Canada à la fin des années 1990, et combinés avec les nombreux commentaires des répondants, donnent une indication des préoccupations auxquelles devrait s'adresser l'Association canadienne de linguistique. La Conclusion donne un résumé de ces questions en forme d'une série de recommandations à l'Association. 